\title{
Statin Mencegah Penurunan Kadar Hemoglobin dan Parameter Hematologi Lainnya pada Model Tikus Gagal Ginjal Eksperimental
}

Statin Prevents the Declining of Hemoglobin Level and Other Hematologic Parameters on the Renal Failure Rat Model

\author{
Agian J Barinda ${ }^{1,2}$, Wawaimuli Arozal ${ }^{1 *}$, Ulfa T Wahyuni ${ }^{3}$ \\ ${ }^{1}$ Departemen Farmakologi dan Terapeutik, Fakultas Kedokteran Universitas Indonesia \\ ${ }^{2}$ Klaster Metabolik, Kardiovaskular, dan Aging, Indonesia Medical Education and \\ Research Institute (IMERI), Fakultas Kedokteran Universitas Indonesia \\ ${ }^{3}$ Program Magister Ilmu Biomedik, Fakultas Kedokteran Universitas Indonesia \\ Jalan Salemba Raya No.6, Jakarta, 10430, DKI Jakarta, Indonesia \\ *Penulis Korespondensi \\ Email:wawaimuli.arozal@ui.ac.id
}

Received: January 25, 2021

Accepted: August 8, 2021

\begin{abstract}
Abstrak
Penyakit Ginjal Kronis (PGK) telah menjadi perhatian serius di dunia. Anemia adalah kondisi yang umum terjadi pada PGK dan menjadi faktor risiko penting dalam terjadinya Penyakit Kardiovaskular (PKV) di PGK. Statin adalah salah satu obat dislipidemia yang sering digunakan untuk mencegah faktor risiko PKV namun penggunaannya menjadi hal yang kontroversial pada kasus PGK berat. Tujuan penelitian ini adalah melihat efek statin (simvastatin) terhadap parameter hematologi dalam model 5/6 Nefrektomi (5/6Nx) sebagai representasi model gagal ginjal berat pada tikus. Pemberian statin secara oral dengan dosis $10 \mathrm{mg} / \mathrm{kgBB}$ diberikan setiap hari selama 30 hari pada kelompok 5/6Nx, kemudian dianalisis parameter hematologi dan dibandingkan dengan kelompok sham (kelompok yang tidak dilakukan nefrektomi dan tidak diberikan obat) dan kelompok 5/6Nx tanpa statin. Hasil penelitian ini didapatkan adanya penurunan kadar Hemoglobin $(\mathrm{Hb})$, Hematokrit $(\mathrm{Ht})$, dan eritrosit secara signifikan pada kelompok 5/6Nx dibandingkan dengan kelompok Sham sedangkan leukosit cenderung menurun pada kelompok 5/6Nx. Statin mencegah penurunan kadar $\mathrm{Hb}, \mathrm{Ht}$, dan leukosit pada kelompok $5 / 6 \mathrm{Nx}+$ statin dibanding kelompok 5/6Nx. Hasil tersebut memperlihatkan efek pleiotropik baru dari statin dalam mencegah penurunan kadar Hb pada PGK. Simpulan dari penelitian ini adalah statin mampu mencegah penurunan kadar $\mathrm{Hb}$ yang terjadi pada model tikus 5/6 Nefrektomi $(5 / 6 \mathrm{Nx})$ sebagai representasi model gagal ginjal berat.
\end{abstract}

Kata kunci: anemia; gagal ginjal; inflamasi; statin

\begin{abstract}
Chronic Kidney Disease (CKD) has raised a serious concern worldwide. Anemia is a common feature in CKD and becomes a significant risk factor for developing Cardiovascular Disease (CVD) in CKD. Statin, as one of the dyslipidemia drugs, is frequently used for preventing $C V D$ risk factors. However, the use of statin on severe CKD still has become controversial. The purpose of this study is to elucidate the effect of statin (simvastatin) on the hematologic parameters in the 5/6 Nephrectomy model as a representative of the severe renal failure model
\end{abstract}




\section{Research Article}

in rats. Statin was given orally at $10 \mathrm{mg} / \mathrm{kg} B W$ every day for 30 days of treatment on the $5 / 6 \mathrm{Nx}$ group, and hematological parameters were be analyzed and compared with the sham group (negative control) and 5/6Nx group without statin treatment. This study showed that the reduction of $\mathrm{Hb}, \mathrm{Ht}$, and Erythrocyte levels was detected significantly in the 5/6Nx group compared with the Sham group. Statin has prevented the reduction of $\mathrm{Hb}, \mathrm{Ht}$, and leucocyte levels in the $5 / 6 N x+$ statin group compared with the 5/6Nx group. In conclusion, we showed that statin could prevent the reduction of $\mathrm{Hb}$ level on the $5 / 6 \mathrm{Nx}$ group as the representative of the severe renal failure model.

Keywords: anemia; renal failure; inflammation; statin

\section{Pendahuluan}

Penyakit ginjal kronis (PGK) terjadi akibat penurunan fungsi ginjal secara bertahap yang terjadi dalam tiga bulan terakhir. Pada tahun 2017 diperkirakan terdapat 697,5 juta kasus PGK di dunia dengan sekitar lebih dari sepuluh juta kasus di Indonesia. ${ }^{1}$ Terdapat sekitar 1,2 juta kematian pada kasus PGK di dunia yang membuat jumlah kematian tersebut meningkat menjadi 41,5\% antara tahun 1990 dan 2017. ${ }^{2}$ Di antara penyebab kematian pada kasus PGK, komplikasi kardiovaskular turut menyumbang angka tertinggi dalam kejadian mortalitas tersebut.

Anemia merupakan salah satu karakteristik yang umum dijumpai pada pasien PGK. Insiden anemia tersebut cenderung meningkat terutama pada pasien PGK dengan derajat berat. Diperkirakan anemia terdeteksi pada hampir semua pasien PGK derajat 4 dan 5. Anemia pada PGK dapat meningkatkan risiko mortalitas PGK akibat komplikasi kardiovaskular, sehingga diperlukan strategi optimal dalam mengatasi anemia yang terjadi pada kasus PGK. ${ }^{3}$

Inflamasi kronis pada PGK merupakan salah satu penyebab yang dapat memicu terjadinya anemia. Proses inflamasi tersebut akan menghambat fungsi eritropoetin maupun meningkatkan level Hepcidin yang diregulasi oleh makrofag sebagai regulator negatif dari metabolisme besi yang akan meningkatkan risiko anemia. ${ }^{4}$ Dalam hal ini, penekanan inflamasi sistemik bermanfaat dalam meningkatkan produksi eritropoetin maupun metabolisme besi

Statin adalah obat penghambat enzim Hydroxymethylglutaryl-CoA (HMG-CoA) reductase yang lazim digunakan sebagai obat dislipidemia untuk mencegah penyakit jantung koroner yang terjadi pada pasien PGK. Statin diketahui mempunyai efek "pleiotropik" yang bermanfaat, salah satunya berupa anti-inflamasi sehingga secara logika statin dapat menjadi kandidat farmakologi anti inflamasi pada pasien PGK. ${ }^{5}$ Penggunaan statin pada PGK berat seperti pada derajat 4 atau 5 masih menjadi hal yang kontroversial. Beberapa literatur menyebutkan bahwa statin cukup aman dan dapat ditoleransi dengan baik pada PGK. ${ }^{6}$ Akan tetapi penelitian kohort retrospektif dan meta-analisis yang menganalisis penggunaan statin jangka panjang 


\section{Research Article}

memperlihatkan bahwa obat tersebut berisiko meningkatkan insiden gagal ginjal akut maupun kronis. $^{7,8}$

Dalam kaitannya dengan proses metabolisme besi, statin menghambat proses inflamasi dengan menurunkan kadar ferritin dalam darah yang berperan penting dalam homeostasis besi. ${ }^{9}$ Studi pada pasien PGK nonhemodialisis memperlihatkan bahwa statin dapat meningkatkan respons obat Erythropoiesis-Stimulating Agents (ESA) dalam membantu proses eritropoesis pasien tersebut. ${ }^{10}$ Peran statin dalam kasus anemia pada CKD masih menjadi hal yang kontroversial Tujuan penelitian ini adalah menganalisis efek statin terhadap perubahan hematologi pada tikus yang diberi perlakuan prosedur 5/6 Nefrektomi $(5 / 6 \mathrm{Nx})$ sebagai representasi model gagal ginjal derajat $4 / 5$.

\section{Metode}

Penelitian ini merupakan penelitian eksperimental pada hewan coba dengan menggunakan tikus Sprague-Dawley (SD). Sebanyak 12 tikus SD jantan berusia dua belas minggu berat badan 150-200 gram diperoleh dari Badan Penelitian dan Pengembangan (Balitkes) Kementrian Kesehatan. Tikus dipelihara di Laboratorium Hewan Coba, Indonesia Medical Education and Research Institute (IMERI), Fakultas Kedokteran Universitas Indonesia (FKUI) dan penelitian ini telah mendapat persetujuan dari Komite Etik Penelitian FKUI dengan SK: KET380UN2.F1/ETIK/PPM.00.02/2019

Tikus SD dipelihara dalam suhu ruangan sekitar $25^{\circ} \mathrm{C}$ dengan kelembaban 55\%, dan dalam siklus terang/gelap setiap 12 jam. Tikus diberi diet standar dan air ad libitum. Setelah dilakukan aklimatisasi selama tujuh hari, dilakukan randomisasi pada tikus tersebut dan dibagi menjadi tiga kelompok yaitu: kelompok sham (kelompok yang tidak dilakukan nefrektomi dan tidak diberikan obat) sebagai kelompok kontrol, kelompok 5/6 Nefrektomi (5/6Nx), dan kelompok 5/6 nefrektomi mendapatkan perlakuan simvastatin $10 \mathrm{mg} / \mathrm{kgBB}(5 / 6 \mathrm{Nx}+$ statin). Pemberian obat dilakukan setiap hari selama 30 hari sebanyak satu kali. Prosedur 5/6 Nx dilakukan dengan cara mengambil ginjal kanan, kemudian polus superior dan inferior ginjal kiri diambil seminggu setelah pengambilan ginjal kanan. Setelah dilakukan prosedur 5/6Nx, kelompok $5 / 6 \mathrm{Nx}+$ statin mendapatkan terapi simvastatin secara oral 30 menit sebelum pemberian diet pakan setiap pagi selama satu bulan sebanyak $10 \mathrm{mg} / \mathrm{KgBB}$ pada tiap tikus. Pada kelompok sham dilakukan insisi lapisan perut tanpa disertai pengambilan organ ginjal, kemudian dilakukan penjahitan pada lapisan perut kembali. Pada akhir perlakuan, dilakukan terminasi pada seluruh 


\section{Research Article}

tikus dan sampel darah diambil untuk pemeriksaan hematologi. Pemeriksaan hematologi dilakukan di Laboratorium Farmakokinetik, Departemen Farmakologi dan Terapeutik, FKUI dengan menggunakan alat Hematology Analyzer Mindray BC 2800.

Data penelitian dan grafik dianalisis dan dibuat dengan GraphPad Prism versi 6.00. Hasil analisis data dipresentasikan dalam bentuk rerata (mean) dan standar deviasi. Analisis statistika antar kelompok dilakukan dengan menggunakan ANAVA satu arah yang diikuti dengan uji lanjut Tukey. Signifikansi didapatkan jika data mempunyai nilai $p$ kurang dari 0,005 $(\mathrm{p}<0,005)$.

\section{Hasil}

Analisis darah ditinjau dari beberapa parameter hematologi tercantum pada tabel 1 .

\section{Tabel 1 Parameter Hematologi}

\begin{tabular}{cccc}
\hline \multirow{2}{*}{ Parameter Hematologi } & \multicolumn{3}{c}{ Kelompok } \\
\cline { 2 - 4 } & Sham & $5 / 6 \mathrm{Nx}$ & $5 / 6 \mathrm{Nx}+$ statin \\
\hline Hemoglobin $(\mathrm{g} / \mathrm{dL})$ & $12,2 \pm 1,04 * *$ & $7,54 \pm 2,28$ & $10,38 \pm 1,34 *$ \\
Hematokrit $(\%)$ & $38,85 \pm 0,58 *$ & $28,5 \pm 8,35$ & $34 \pm 3,65$ \\
MCV $(\mathrm{fL})$ & $62,03 \pm 1,53$ & $60,2 \pm 6,74$ & $58,98 \pm 1,23$ \\
MCH $(\mathrm{pg})$ & $21,17 \pm 1,39$ & $16,78 \pm 1,88$ & $17,88 \pm 0,92$ \\
MCHC $(\mathrm{g} / \mathrm{dL})$ & $342 \pm 18,25$ & $291,25 \pm 18,03$ & $304,25 \pm 16,68$ \\
Eritrosit $\left(10^{6} / \mu \mathrm{L}\right)$ & $6,67 \pm 0,54 *$ & $5,35 \pm 1,09$ & $5,77 \pm 0,53$ \\
Leukosit $\left(10^{3} / \mu \mathrm{L}\right)$ & $9,63 \pm 1,39$ & $7,32 \pm 1,99$ & $9,95 \pm 4,95$ \\
Trombosit $\left(10^{5} / \mu \mathrm{L}\right)$ & $6,09 \pm 1,29$ & $7,13 \pm 2,26$ & $7,13 \pm 3,16$
\end{tabular}

Sham: Kelompok perlakuan sham; 5/6 Nx: Kelompok perlakuan 5/6 nefrektomi; 5/6 Nx+statin: Kelompok perlakuan 5/6 Nefrektomi dan statin

${ }^{*}$ : Berbeda bermakna $(\mathrm{p}<0,05)$ dibandingkan dengan kelompok 5/6 Nx (Nefrektomi)

${ }^{* *}$ : Berbeda bermakna $(\mathrm{p}<0,01)$ dibandingkan dengan kelompok 5/6 Nx (Nefrektomi)

Analisis kadar Hemoglobin $(\mathrm{Hb})$ maupun Hematokrit $(\mathrm{Ht})$ menunjukkan terjadinya penurunan $\mathrm{Hb}$ maupun $\mathrm{Ht}$ pada kelompok tikus 5/6Nx dibandingkan dengan kelompok Sham. Terapi statin secara bermakna dapat meningkatkan kadar $\mathrm{Hb}$ pada kelompok $5 / 6 \mathrm{Nx}+$ statin dibandingkan dengan kelompok 5/6Nx dan tidak ada perbedaan signifikan antara kelompok 5/6Nx+stating dan kelompok sham (gambar 1). Berdasarkan data tersebut, dapat disimpulkan bahwa statin dapat mencegah penurunan $\mathrm{Hb}$ yang terjadi pada tikus yang mendapatkan prosedur $5 / 6 \mathrm{Nx}$. 


\section{Research Article}

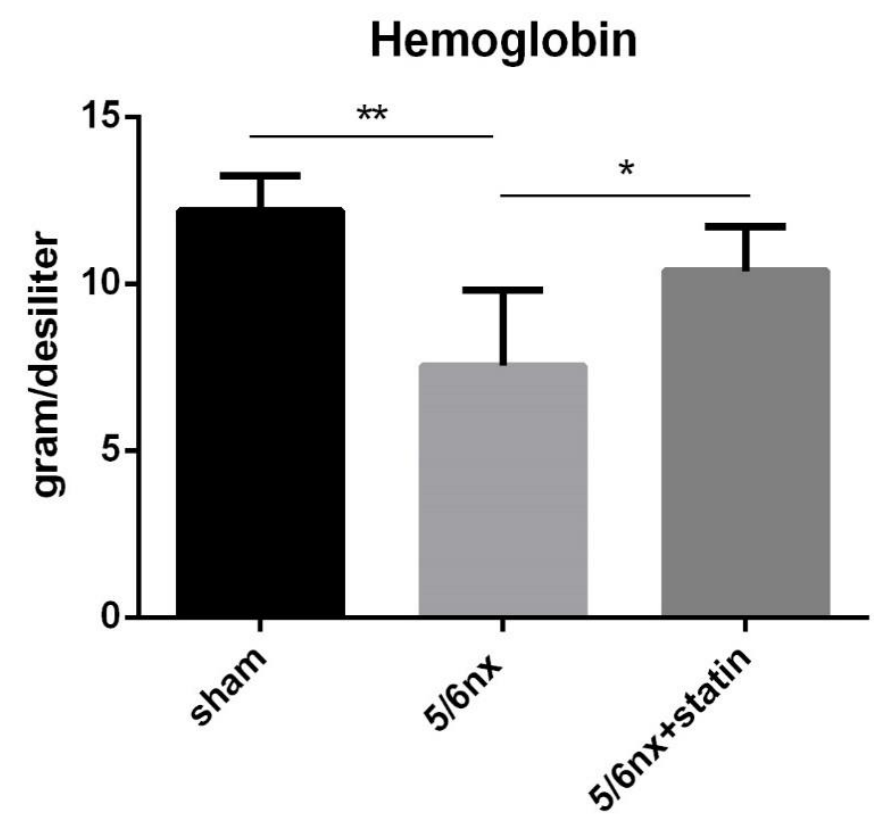

\section{Gambar 1 Analisis Kadar Hemoglobin Dalam Darah}

Keterangan :

Sham: Kelompok perlakuan sham; 5/6 Nx: Kelompok perlakuan 5/6 nefrektomi; 5/6 Nx+statin: Kelompok perlakuan 5/6 Nefrektomi dan statin

${ }^{*}$ : Berbeda bermakna $(\mathrm{p}<0,05)$ dibandingkan dengan kelompok 5/6 Nx (Nefrektomi)

${ }^{* *}$ : Berbeda bermakna $(\mathrm{p}<0,01)$ dibandingkan dengan kelompok $5 / 6 \mathrm{Nx}($ Nefrektomi)

Pada tabel 1 dapat dilihat bahwa tidak terdapat perbedaan $\mathrm{MCV}, \mathrm{MCH}$, dan $\mathrm{MCHC}$ antara kelompok Sham, 5/6Nx, dan 5/6Nx+statin. Perlakuan 5/6Nx maupun pemberian statin tidak mempengaruhi parameter $\mathrm{MCV}, \mathrm{MCH}$, dan $\mathrm{MCHC}$ tersebut. Sejalan dengan perubahan $\mathrm{Hb}$ tersebut, pada tabel 1 terlihat bahwa terjadi penurunan jumlah eritrosit pada kelompok 5/6Nx dibandingkan dengan kelompok sham meskipun statin tidak mampu meningkatkan jumlah eritrosit pada kelompok 5/6N+statin. Terdapat kecenderungan penurunan jumlah leukosit pada kelompok 5/6Nx meskipun tidak terjadi secara bermakna dibandingkan dengan kelompok Sham maupun $5 / 6 \mathrm{~N}+$ statin. Tdak ditemukan adanya perbedaan dari jumlah trombosit pada ke tiga kelompok tersebut.

\section{Diskusi}

Anemia adalah kelainan yang sering terjadi pada PGK dan dapat meningkatkan risiko mortalitas PGK akibat komplikasi kardiovaskular. ${ }^{3}$ Penurunan kadar $\mathrm{Hb}$ dan $\mathrm{Ht}$ terdeteksi pada kelompok tikus $5 / 6 \mathrm{Nx}$ dan pemberian statin mampu mencegah terjadinya penurunan kadar 


\section{Research Article}

tersebut pada tikus yang mendapatkan perlakuan $5 / 6 \mathrm{Nx}$ (tabel 1 dan gambar 1). Inflamasi diketahui mempunyai penting terjadinya anemia pada PGK. ${ }^{3}$ Hepcidin adalah hormon yang disekresikan oleh organ hati dan berperan dalam regulasi negatif homestasis besi dalam tubuh. Proses inflamasi yang terjadi pada PGK diketahui mengaktivasi hormon tersebut sehingga menghambat proses metabolisme besi. ${ }^{11}$

Dislipidemia adalah salah satu faktor risiko yang dapat meningkatkan risiko kardiovaskular pada PGK. ${ }^{12}$ Statin adalah obat dislipidemia yang lazim digunakan untuk mencegah proses aterosklerosis yang terjadi pada PGK dengan menekan jalur mevalonate yang nantinya akan menghambat sintesis kolesterol. ${ }^{5}$ Statin diketahui juga mempunyai efek pleitropik berupa anti-inflamasi sehingga diharapkan mampu menekan proses inflamasi pada PGK. ${ }^{5}$ Supresi jalur inflamasi tersebut dapat menghambat ekspresi Hepcidin dan mencegah penurunan kadar $\mathrm{Hb}$. Simvastatin dapat menghambat ekspresi Hepcidin pada sel hepatoma HepG2. ${ }^{13}$ Atorvastatin, jenis lain dari statin, juga dapat menekan sitokin inflamasi Interleukin-6 (IL6) maupun HsCRP sehingga menghambat ekspresi Hepcidin pada pasien PGK derajat 3 dan 4. Inaktivasi hepcidin tersebut kemudian mampu meningkatkan proses metabolisme besi dan mencegah anemia pada pasien tersebut. ${ }^{14}$ Pemberian terapi statin juga mampu meningkatkan sensitivitas respon obat Erythropoiesis-Stimulating Agent (ESA) yang nantinya berperan dalam eritropoesis pada pasien PGK yang belum mendapatkan hemodialisis. ${ }^{10}$

Jumlah eritrosit dan leukosit terlihat menurun pada kelompok 5/6Nx meskipun penurunan jumlah leukosit tidak terjadi secara signifikan pada kelompok tersebut (tabel 1). Pada kelompok $5 / 6 \mathrm{Nx}+$ statin didapatkan bahwa statin dapat mencegah kejadian leukopenia pada tikus model 5/6Nx. Penurunan jumlah eritrosit maupun leukosit dapat terdeteksi pada PGK. ${ }^{15}$ Disfungsi sumsum tulang pada pasien PGK menjadi salah satu penyebab dari penurunan jumlah sel darah tersebut ${ }^{16}$ dan pada penelitian kami ditemukan bahwa statin dapat mencegah penurunan jumlah leukosit pada tikus yang mendapatkan $5 / 6 \mathrm{Nx}$.

Keterbatasan dari penelitian ini adalah jumlah sampel yang terbatas, hal ini dikarenakan terdapat beberapa sampel yang mati akibat perlakuan prosedur 5/6NX. Penelitian lanjutan dengan sampel yang lebih banyak diperlukan untuk meningkatkan reliabilitas pada studi ini. Selain itu, penelitian lanjutan juga diperlukan dalam menganalisis korelasi antara status inflamasi, hepcidin, dan metabolisme besi untuk melihat lebih detail mekanisme molekular statin dalam mencecgah kejadian anemia pada PGK. 


\section{Research Article}

\section{Simpulan}

Statin mampu mencegah penurunan kadar $\mathrm{Hb}$ yang terjadi pada tikus yang diberikan perlakuan prosedur 5/6 Nefrektomi (5/6Nx) sebagai representasi model gagal ginjal derajat 4/5.

\section{Daftar Pustaka}

1. Bikbov B, Purcell CA, Levey AS, Smith M, Abdoli A, Abebe M, et al. Global, Regional, and National Burden of Chronic Kidney Disease, 1990-2017: A Systematic Analysis for the Global Burden of Disease Study 2017. The Lancet. 2020;395(10225):709-33.

2. Carney EF. The Impact of Chronic Kidney Disease on Global Health. Nat Rev Nephrol. 2020;16(5):251.

3. Kutuby F, Wang S, Desai C, Lerma EV. Anemia of Chronic Kidney Disease. Dis Mon. 2015;61(10):421-4.

4. Begum S, Latunde-Dada GO. Anemia of Inflammation with An Emphasis on Chronic Kidney Disease. Nutrients. 2019;11(10):2424-56.

5. Diamantis E, Kyriakos G, Quiles-Sanchez LV, Farmaki P, Troupis T. The Anti-Inflammatory Effects of Statins on Coronary Artery Disease: An Updated Review of the Literature. Curr Cardiol Rev. 2017;13(3):209-16.

6. Kalaitzidis RG, Elisaf MS. The Role of Statins in Chronic Kidney Disease. Am J Nephrol. 2011;34(3):195-202.

7. Acharya T, Huang J, Tringali S, Frei CR, Mortensen EM, Mansi IA. Statin Use and the Risk of Kidney Disease With Long-Term Follow-Up (8.4-Year Study). Am J Cardiol. 2016;117(4):647-55.

8. Su X, Zhang L, Lv J, Wang J, Hou W, Xie X, et al. Effect of Statins on Kidney Disease Outcomes: A Systematic Review and Meta-analysis. Am J Kidney Dis. 2016;67(6):881-92.

9. Zacharski LR, DePalma RG, Shamayeva G, Chow BK. The Statin-Iron Nexus: Anti-Inflammatory Intervention for Arterial Disease Prevention. Am J Public Health. 2013;103(4):e105-12.

10. Sui Z, Wang M, Zuo L. Statin Therapy and Erythropoiesis-Stimulating Agent Hyporesponsiveness in Patients with Nondialysis Chronic Kidney Disease: A Retrospective Study in Beijing, China. Medicine (Baltimore). 2019;98(2):e13981.

11. Ganz T, Nemeth E. Iron Balance and the Role of Hepcidin in Chronic Kidney Disease. Semin Nephrol. 2016;36(2):87-93.

12. Mikolasevic I, Zutelija M, Mavrinac V, Orlic L. Dyslipidemia in Patients with Chronic Kidney Disease: Etiology and Management. Int J Nephrol Renovasc Dis. 2017;10:35-45.

13. Chang CC, Chiu PF, Chen HL, Chang TL, Chang YJ, Huang CH. Simvastatin Downregulates the Expression of Hepcidin and Erythropoietin in HepG2 cells. Hemodial Int. 2013;17(1):116-21.

14. Masajtis-Zagajewska A, Nowicki M. Effect of Atorvastatin on Iron Metabolism Regulation in Patients with Chronic Kidney Disease - A Randomized Double Blind Crossover Study. Ren Fail. 2018;40(1):700-9.

15. Habib A, Ahmad R, Rehman S. Hematological Changes in Patients of Chronic Renal Failure and the Effect of Hemodialysis on These Parameters. International Journal of Research in Medical Sciences. 2017;5(11): 49985003.

16. Arai Y, Kanda E, Iimori S, Naito S, Noda Y, Sasaki S, et al. Low White Blood Cell Count is Independently Associated with Chronic Kidney Disease Progression in the Elderly: the CKD-ROUTE study. Clin Exp Nephrol. 2018;22(2):291-8. 